O. L. Kyrychenko ${ }^{1}$, Cand. Sc. (Tech.), orcid.org/0000-0002-1331-9323,

V.V. Kulivar ${ }^{2}$, orcid.org/0000-0002-7817-9878,

O.V. Skobenko ${ }^{2}$, Cand. Sc. (Tech.), Assoc. Prof., orcid.org/0000-0003-4606-4889,

O.V. Khalymendyk ${ }^{2}$, Cand. Sc. (Tech.), Assoc. Prof., orcid.org/0000-0002-1311-1135
1 - State Enterprise "Research-Industrial Complex "Pavlohrad Chemical Plant”, Pavlohrad, Dnipropetrovsk Region, Ukraine, e-mail: alekseyphz@gmail.com

2 - Dnipro University of Technology, Dnipro, Ukraine

\title{
A TECHNIQUE TO MEASURE SENSITIVITY OF EXPLOSIVES TO THE EFFECT OF LASER PULSE RADIATION
}

Purpose. Improving reliability of the technique to determine sensitivity of explosives to laser pulse radiation involving the method for defining function of energy distribution in a laser beam.

Methodology. Experimental studies, physical and mathematical modeling.

Findings. The available techniques to determine sensitivity of explosives to laser pulse radiation have been analyzed. The technique to define the function of energy distribution in a laser beam is rather simple not requiring complex experimental equipment.

Originality. Regularities of energy density distribution within the laser ray cross-section have been determined. It has been demonstrated that both theoretical and experimental dependences of energy density upon the laser ray radius are characterized by Gaussian distribution being little different from each other. Changes in radiation intensity within the laser ray cross-section have been determined experimentally.

Practical value. Practical use of the laser initiation technique is connected with the improvement of the known methods to develop profiled detonation waves within the explosive charges as well as plane, cylindrical, conical, and spherical shock waves in different materials. Methods to develop such waves are characterized by maximum high repeatability of results and high efficiency in terms of minimum possible power consumption.

Keywords: explosive, laser, radiation, pulse, sensitivity, initiation, explosion, energy

Introduction. Studies on physical and mathematical regularities of a previously determined phenomenon of initiation of the detonation in explosives by laser radiation [1] are rather topical tasks of chemical [2] and laser physics [3] as well as blasting practices [4]. A process of laser initiation of explosives which are characterized by different sensitivity has been considered in a series of theoretical and experimental works carried out in the USA, Russia, Japan, Ukraine and other countries; the studies began 50 years ago being still topical today. Despite the fact that certain important fundamental results have been obtained in this area and considerable practical knowledge has been accumulated, there is still no uniform technique to measure sensitivity of explosives to laser radiation [5].

Being transparent to laser radiation, condensed explosives both in the form of fine-grained powder and in solid state are the medium with dense packing of diffusers. These are the substances requiring correct determination of the concept of sensitivity to laser pulse. The matter is that the major share of laser radiation falling onto the energy-saturated substances is scattered in a diffusive way in opposite direction [6]. Moreover, crystals of the substance, which are in the inner layers of the explosive, play a defining role in the diffusion. If the explosive thickness is less than the inverse value of the attenuation rate, then a certain share of radiation passes through a sample without going back; consequently, it does not contribute to the heating of microinclusions. The light mode in such a sample differs from the light mode in a half-space consisting of the explosive [7]. This will influence both diffuse reflection factor and laser ignition parameters [8].

The abovementioned means that such characteristics of a substance as a diffuse reflection factor and sensitivity are the characteristics of a certain explosive only in case if sample thickness is much more than the inverse value of the radiation attenuation rate.

Consider the determination of the explosive sensitivity to the effect of pulse laser radiation. Depending upon the features of the tasks to be solved, there may be different defini-

(C) Kyrychenko O. L., Kulivar V.V., Skobenko O. V., Khalymendyk O. V., 2019 tions of such concept as sensitivity. Thus, while solving the problems concerning determination of the mechanism of laser initiation of explosives, sensitivity is defined as a minimum value of the absorbed energy of radiation resulting in the explosive ignition, i.e.

$$
E_{q}^{*}=E_{q}(1-R)
$$

where $E_{q}$ is density of the energy of laser radiation falling onto the explosive sample; $R$ is the diffuse reflection factor.

While solving engineering problems, we interpret sensitivity as a minimum density of laser radiation energy resulting in the explosive blasting. Such a definition of sensitivity is not accurate since it does not take into consideration the fact that the explosion near the initiation threshold is of probabilistic character both in terms of laser ignition and in terms of other types of effect (impact, impression, etc.). Thus, currently, it is conventional to understand sensitivity of explosives to the effect of pulse laser radiation as density of energy $E_{q}^{*}$ which corresponds to $50 \%$ of the initiation probability [9].

Methods. While studying sensitivity, preliminary experiments are carried out to determine the density range of energies that corresponds to the area whose energy initiates probable explosion of the explosive charge. After that, 25-30 samples of explosives are tested within the range of probable initiation. Processing of blasting frequency histogram results in the developed dependence of the initiation upon the density of laser energy $\omega\left(E_{q}^{*}\right)$. It is the density of energy $E_{q}^{*} *$, for which $\omega\left(E_{q}^{*}\right)=0.5$, that is the characteristic of explosive sensitivity to the laser pulse effect. The following value is selected as the characteristic of the width of probable blasting zone

$$
\frac{\partial E_{q}^{*}}{\partial \omega}(\omega=0.5)
$$

Studies of the explosive sensitivity to the effect of pulse laser radiation began with the use of simplest optical recording circuits. Accumulation of practices concerning a laser ignition mechanism has resulted in the increased requirements for initiation and recording circuits. Topicality is in the fact that 
while searching for and synthesizing light-sensitive explosives, first of all, it is required to test explosives as for determining possibility of their laser pulse ignition.

Taking into consideration the fact that sensitivity of different explosives to laser radiation may differ by several orders, preliminary tests of energy-saturated substances are carried out using a simplest optical circuit which makes it possible to vary density of radiation energy within wide ranges (Fig. 1).

To simulate accurately the geometrical conditions, the distance from beam splitter 4 to diaphragm 6 of the explosive sample was selected to be equal $L_{1}=L_{2}$. While determining OQG 1 energy efficiency, falling onto a calorimeter, the explosive sample is substituted with one more calorimeter with a diaphragm whose diameter is equal to the one of the diaphragm 6. Energy efficiency is determined as a result of a series of control shots. Further, while testing the explosives, the angle of splitter 4 relative to the laser ray is the same as during control measurements.

Scattering lens 3 helps to change energy density on the explosive sample. Light filter 2 is used to eliminate possible illumination of the explosive by the light from a pumping lamp of an optical quantum generator (OQG).

A disadvantage of the available technique and optical circuit of its implementation is in the approximated determination of threshold energy density since it is defined by dividing the calorimeter-measured energy by the area of a diaphragm hole, i. e. energy distribution within the diaphragm hole is not taken into consideration.

If we use OQG with the direction of the vector of radiation polarization which changes from one monopulse generation to another, the angle between a normal to the splitter surface and direction of radiation propagation is selected not to be more than $20^{\circ}$. In terms of those range of angles, the coefficient of Fresnel reflection does not depend upon the direction of a radiation polarization vector. It should be noted that it is possible to interchange sample 5 and calorimeter 7 along with diaphragm 6 in order to measure minor energy densities and improve measurement accuracy.

The represented circuit of explosive initiation did not contain any requirements for laser radiation quality. However, according to the papers (published within the period of 1978-1985) by E. Aleksandrov, A. Vozniuk, V.Tsypiliov and others, correct measuring of laser ignition parameters requires use of one-mode one-frequency OQG. It is stipulated by the fact that multimode generators usually used during the experiments develop local lighting discontinuities within the explosive (due to the available complex spatial structure of the light beam) making their measurement impossible.

Purpose of the paper is to improve reliability of the technique to determine explosive sensitivity to laser pulse radiation involving the method for determining the function of energy distribution within a laser beam.

Development of the technique to determine explosive sensitivity to laser pulse radiation is of great importance for practical tasks being topical in machine building - metal reinforcing, stamping, developing new materials and materials with innovative physical properties, during geophysical studies of the earth's crust, in high-parameter mechanics etc. Wide

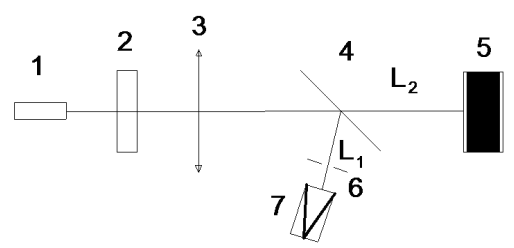

Fig. 1. Circuit of initiation and recording of the explosive sensitivity:

1 - optical quantum generator; 2 - light filter; 3 - lens; 4 - beam splitter; 5 - quantity of explosive; 6 -diaphragm; 7 - calorimeter practical implications of the method of laser initiation are connected with the improvement of the known techniques to develop profiled detonation waves in the explosive charges and shock waves in metals. (e.g. flat [10] converging to the center of the sphere - spherical [11], converging to the axis - cylindrical and conic [12, 13]).

Theoretical and experimental studies. Consider certain peculiarities of the technique to determine the function of energy distribution in a laser beam [14]. The technique is based on the experimental determination of diameters of the prints, when laser pulse of different energy effects the material undergoing phase transformation being observed visually or with the microscope. Moreover, the phase transfer should be of threshold character, i. e. take place under the effect of laser energy whose density is higher than certain threshold value $E^{*}$. In this case, we obtain contrast prints whose sizes may be measured to the high accuracy. Color paper with a thin layer of a coloring agent changing its color during laser action was used as such a material. The main requirement for the technique is as follows: the function of distribution of radiation intensity within the beam cross-section should not vary from pulse to pulse. The requirement was met in terms of stable OQG operation generating pulses of similar energy. Calibrated light filters were used to change density of radiation energy.

Determine distribution of energy density within the beam cross-section as follows

$$
E(r)=E_{0} \omega(r),
$$

where $E_{0}$ is energy density in the beam center; $r$ is the radius of the circle where the value of $E(r)$ should be found.

Representation of the function of energy density in the form of (1) means radial symmetry of the distribution function. Normalize this function by total energy pulse $W$

$$
W=2 \pi E_{0} \int_{0}^{\infty} \omega(r) r d r
$$

Having divided (1) by (2), we obtain

$$
E(r) / W=\omega(r) / 2 \pi k,
$$

where $k=\int_{0}^{\infty} \omega(r) r d r$

While changing laser path transmittance, we obtained a set of prints whose radii were measured with the help of microscope. Boundaries of prints correspond to the threshold energy of color change $E^{*}$. Using the measurement results, represent a system of equations as follows

$$
E^{*} / W_{i}=\omega\left(r_{i}\right) / 2 \pi k, \quad i=\overline{I, n},
$$

where $n$ is the number of changes; $W_{i}$ is energy of radiation in terms of which the print radius is equal to $r_{i}$.

Having developed dependence $W(r)$ by extrapolation method, we find energy $W(0)$ at which print radius is equal to zero. For that energy

$$
E^{*}=/ W(0)=\omega(0) / 2 \pi k-I / 2 \pi k .
$$

Having divided in sequence the equations of system (3) by equation

$$
\omega\left(r_{i}\right)=W(0) / W_{i}, \quad i=\overline{I, n} .
$$

If distribution function $\omega\left(r_{i}\right)$ is known, it helps to solve the problem completely. To determine energy density in the beam center, it is required to determine value $k$ by means of integration; value $E_{0}$ is calculated according to formula

$$
E_{0}=W /(2 \pi k) \text {. }
$$

The technique was used while determining the function of energy density distribution within a laser beam generated by 
OQG Bigsky Laser CFA 200/400 (USA) during its operation in the mode of resonator Q-switching.

Basing upon the dependence $W_{i}\left(r_{i}\right)$, demonstrated in Fig. 2, determine energy $W(r)$ at which the print radius is equal to zero: $W(r)=2.5 \mathrm{~mJ}$. Ratios (5) make it possible to define values of the distribution function $\left(r_{i}\right)$, Fig. 3. Having developed the function $r_{i} \omega\left(r_{i}\right)$ (Fig. 4), we apply numerical integration to obtain the value of integral $k=4.5 \cdot 10^{-3} \mathrm{~cm}^{2}$ that is required for determining energy density in the center of beam $E_{0}$ and, consequently, $E(r)$ function as well. Table represents value $E_{0}$ and average values of energy density in terms of print $E_{a v}=\frac{W}{\pi r_{i}^{2}}$.

It is obvious that one cannot use value $E_{a v}$ in terms of experimental studies as it depends upon the material on which sizes of prints are determined.

The following distribution of energy density $E(r)$ is convenient to be represented in an analytical form for further experimental studies.

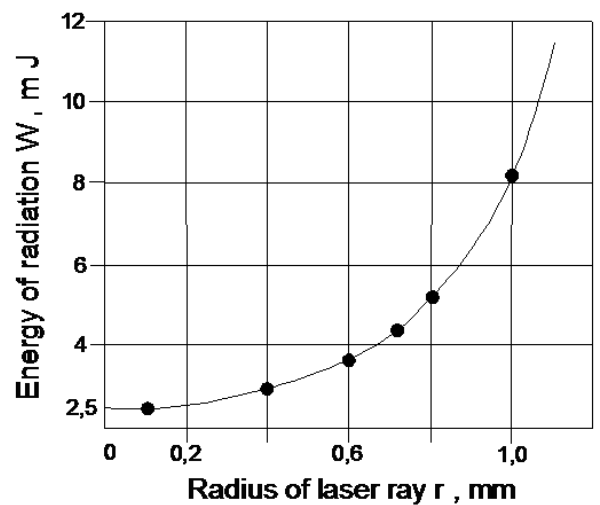

Fig. 2. Intensity of radiation within the laser ray cross-section

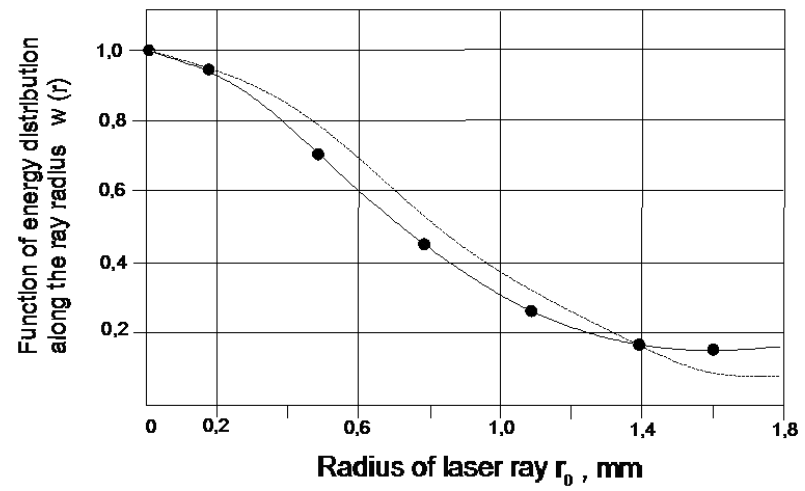

Fig. 3. Gaussian distribution of function $\omega(r)-1 ; 2-$ experimental function of distribution $\omega(r)$

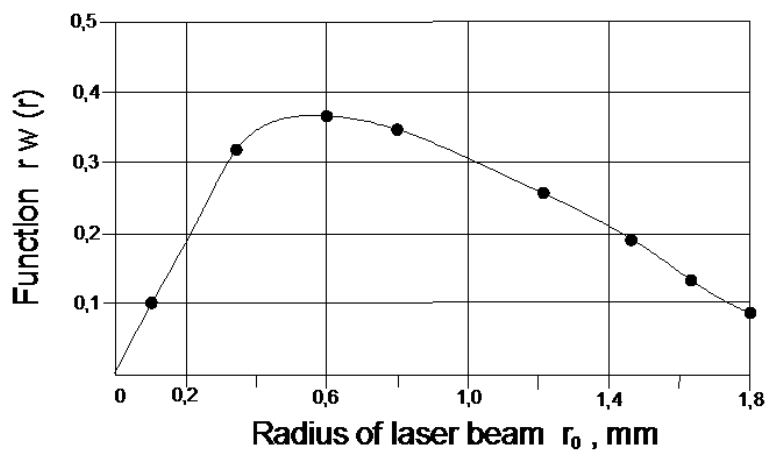

Fig. 4. Dependence of the value of function $r \omega(r)$ upon the radius of laser ray
Table

Experimental values of the parameters required to determine functions of radiation intensity distribution within the laser beam cross-section

\begin{tabular}{|c|c|c|c|c|c|c|}
\hline No. & $\begin{array}{c}r_{i}, \\
\mathrm{~mm}\end{array}$ & $\begin{array}{c}W_{i}, \\
\mathrm{~mJ}\end{array}$ & $\omega\left(r_{i}\right)$ & $\begin{array}{c}E_{0}, \\
\mathrm{~mJ} / \mathrm{cm}^{2}\end{array}$ & $\begin{array}{c}E_{a v}, \\
\mathrm{~mJ} / \mathrm{cm}^{2}\end{array}$ & $\exp \left(-\frac{r_{i}^{2}}{2 \sigma^{2}}\right)$ \\
\hline 1 & 1.75 & 43.0 & 0.058 & 755 & 449 & 0.034 \\
\hline 2 & 1.62 & 35.1 & 0.071 & 615 & 366 & 0.054 \\
\hline 3 & 1.60 & 34.3 & 0.073 & 601 & 358 & 0.059 \\
\hline 4 & 1.38 & 21.1 & 0.118 & 370 & 221 & 0.12 \\
\hline 5 & 1.12 & 11.6 & 0.216 & 203 & 121 & 0.25 \\
\hline 6 & 1.0 & 8.0 & 0.313 & 140 & 84 & 0.33 \\
\hline 7 & 0.75 & 4.98 & 0.502 & 87 & 52 & 0.54 \\
\hline 8 & 0.56 & 3.89 & 0.643 & 68 & 41 & 0.7 \\
\hline 9 & 0.33 & 2.8 & 0.893 & 49 & 29 & 0.89 \\
\hline 10 & 0.1 & 2.59 & 0.965 & 45 & 27 & 0.89 \\
\hline
\end{tabular}

It is well-known that in case of a single-mode operation of laser, distribution of energy density along the beam cross-section is well approximated by Gaussian distribution. Thus, we represent our distribution by function

$$
E(r)=\frac{W}{2 \pi \sigma^{2}} \exp \left(-\frac{r^{2}}{2 \sigma^{2}}\right),
$$

where $\sigma$ is the parameter of distribution.

Function (7) is normalized for total energy of laser pulse. Transform (7) to (1) form. Find the following from (7)

$$
E_{0}=E(0)=\frac{W}{2 \pi \sigma^{2}},
$$

consequently,

$$
E(r)=E(0) \exp \left(-\frac{r^{2}}{2 \pi \sigma^{2}}\right) .
$$

Comparing (8) with (7) and (9) with (1), we obtain

$$
\sigma^{2}=k \omega(r)=\omega_{r}=\exp \left(-\frac{r^{2}}{2 \sigma^{2}}\right) .
$$

Fig. 3 shows that the function $\omega_{r}$ approximates experimental function of distribution $\omega(r)$ well enough. Analytical representation of energy density distribution within a laser beam is convenient during experimental studies.

The next example. Certain part of experimental studies has been performed with the use of negative lens; it widened the laser beam so that the size of image on the explosive sample increased by a factor of three. It is clear that in this context the distribution function does not change. Transition to a new distribution requires a change of variable $\left(r=(1 / 3) r^{\prime}\right)$ in expression (7). Then

$$
\left(r^{\prime}\right)=\frac{W}{2 \pi \sigma^{2}} \exp \left(-\frac{r^{\prime 2}}{2 \cdot \sigma^{2}}\right) .
$$

While normalizing the function for total energy of laser pulse, we obtain

$$
E\left(r^{\prime}\right)=\frac{W}{2 \pi \sigma^{\prime 2}} \exp \left(-\frac{r^{\prime}}{2 \sigma^{2}}\right),
$$

where $\sigma^{\prime 2}=9 \sigma^{2}$ 
The experiment involved a diaphragm with the diameter of $D=4.5 \mathrm{~mm}$ which cut central part of the beam. Energy $W_{d}$, having passed through a diaphragm and falling onto explosive sample, was measured. Energy density was measured according to formula

$$
E_{a v}=W_{d} /\left(\pi D^{2} / 4\right) .
$$

Using function (11), we determine the energy of laser radiation, having passed through the diaphragm

$$
W_{d}=2 \pi \frac{W}{2 \pi \sigma^{\prime 2}} \int_{0}^{D / 2} \exp \left(-\frac{r^{2}}{2 \sigma^{\prime 2}}\right) r d r=W\left(1-\exp \left(-\frac{D^{2}}{8 \sigma^{\prime 2}}\right)\right) .
$$

Having substituted values of $D$ and $\sigma^{\prime}$ into (13), we obtain

$$
W_{d}=W(1-0.61)=0.39 W .
$$

If we know value $W_{d}$, it is possible to define by how many times energy density in the beam center is more than the average value determined according to formula (12)

$$
\frac{E_{0}}{E_{a v}}=\left(\frac{w}{2 \pi \sigma^{\prime 2}}\right) /\left(\frac{0.39 w}{\frac{\pi D^{2}}{4}}\right)=1.23 .
$$

In terms of the image magnified by 3.3 times and diaphragm $D=7 \mathrm{~mm}$

$$
E(D / 2)=0.7 W ; \quad \frac{E_{0}}{E_{a v}}=1.8 .
$$

Thus, while carrying out experimental studies on explosive sensitivity to the effect of laser pulse, it is required to stipulate, what critical density of the initiation energy corresponds to: maximum values of density in beam $E_{0}$ or average value $E_{a v}$.

The represented technique to determine the function of energy distribution within a laser beam does not require complex experimental equipment.

Conclusion. The determined regularities of interaction between laser radiation and energy-consuming substances and explosive composites in polymer matrix are of considerable interest for laser radiation physics.

Development of the technique to determine explosive sensitivity to laser pulse radiation is of great importance for practical tasks being still topical in machine building - metal reinforcing, stamping, developing new materials and materials with innovative physical properties, during geophysical studies of the earth's crust, in high-parameter mechanics etc. Wide practical implications of the method of laser initiation are connected with the improvement of the known techniques to develop plane, cylindrical, spherical detonation waves and their combinations in the explosive charges as well as shock waves in metals under processing.

The technique has made it possible to obtain maximum effect along with the minimization of costs. All the modern methods to develop profiled detonation waves involve additional mass of explosive (up to $50 \%$ of the primary charge) and a complex structure of so-called generator of profiled waves. Laser initiation is not characterized by those disadvantages.

\section{Reference.}

1. Iliushin, M.A., Tselinskii, I. V., \& Kotomin, A.A. (2013). High power substances for arsenal of initiation. St. Petersburg: SPbGTI(TU) Publ.

2. Iliushin, M., Shugalei, I., \& Sudarikov, A. (2017). Highenergy metal complexes: synthesis, properties, application. Saarbrucken: LAP LAMBERT academic publishing GmbH\&CO. KG.

3. Sazonnikova, N.A. (2013). Laser initiation of high-energy substance detonation. Saarbrucken: LAP LAMBERT Academic Publishing GmbH\&CO.KG.
4. Ananieva, M. V., \& Zykov, I. Yu. (2015). Laser initiation of composites hexogen-aluminium. Molodoy uchenyy, 9, 65-70. 5. Furega, R. I., Aduiev, B.P., \& Nurmukhametov, D. R. (2013). Laser initiation of the mixture of tetranitropentaerytrite and energy-consuming nanoparticles of metals and compounds. Vestnik KepmNGU, 3(3), 113-118.

6. Sobolev, V. V., Chernai, A.V., \& Studinskii, N.M. (1995). On the technique to measure sensitivity of explosives and pulse of explosion product in terms of laser effect. High-energy material treatment. In Sbornik nauchnykh trudov, 1, Dnepropetrovsk: Gosudarstvennaya gornaya akademiya Ukrainy (pp. 136-141). 7. Chernai, A. V., Sobolev, V. V., Chernaj, V. A., Ilyushin, M. A., \& Dlugashek, A. (2003). Laser initiation of charges on the basis of di-(3-hydrazino-4-amino-1,2,3-triazol)-copper (II) perchlorate. FizikaGoreniya i Vzryva, 39(3), 105-110.

8. Sobolev, V. V., Shiman, L. N., Nalisko, N. N., \& Kirichenko, A. L. (2017). Computational modeling in research of ignition mechanismof explosives by laser radiation. Naukovyi Visnyk Natsionalnoho Hirnychoho Universytetu, 6(162), 53-60.

9. Chernai, A.V., Sobolev, V.V., Ilyushin, M.A., Zhitnev, N.E., \& Petrova, N.A. (1996). On the mechanism of ignition of energetic materials by a laser pulse. Chemical Physics Reports 15(3), 457-462.

10. Iliushin, M.A., Sudarikov, A. M., \& Tselinskii, I. V. (Ed.) (2010). Metal complexes in high-energy composites: monograph. St.-Petersburg: Leningradskiy gosudarstvennyy universitet im. A. S. Pushkina.

11. Chernai, A.V., Sobolev, V.V., Ilyushin, M.A., \& Zhitnik, N.E. (1994). The method of obtaining mechanical loading pulses based on a laser initiation of explosion of explosive coatings. Fizika Goreniya i Vzryva, 30(2), 106-111.

12. Chernai, A.V., Sobolev, V.V., Ilyushin, M.A., \& Zhitnik, N.E. (1994). Generating mechanical pulses by the laser blasting of explosive coating. Combustion, Explosion, and Shock Waves, 30(2), 239-242. DOI: 10.1007/BF00786134.

13. Chernai, A. V., \& Sobolev, V.V. (1995). Laser method of profiled detonation wave generation for explosion treatment of materials. Fizika i Khimiya Obrabotki Materialov, 5, 120-123.

14. Kyrychenko, O.1. (2018). On the influence of the density of laser beam energy $\mathrm{n}$ the sensitivity of explosive substances to laser radiation. Naukovyi Visnyk Natsionalnoho Hirnychoho Universytetu, 6(168), 48-56. DOI: 10.29202/nvngu/2018-6/7.

\section{Методика вимірювання чутливості вибухових речовин до дії лазерного імпульсного випромінювання}

\section{О. Л. Кириченко ${ }^{1}$, В. В. Кулівар ${ }^{2}$, О. В. Скобенко ${ }^{2}$, О. В. Халимендик ${ }^{2}$}

1 - Державне підприємство „Науково-виробниче об’єднання „Павлоградський хімічний завод“, м. Павлоград, Дніпропетровська обл., Україна, e-mail: alekseyphz@ gmail.com

2 - Національний технічний університет „Дніпровська політехніка“, м. Дніпро, Україна

Мета. Підвищення надійності й достовірності методики визначення чутливості вибухових речовин (ВР) до лазерного імпульсного випромінювання з використанням методики визначення функції розподілу енергії в лазерному пучку.

Методика. Експериментальні дослідження та фізикоматематичне моделювання.

Результати. Проведено аналіз існуючих методів визначення чутливості вибухових речовин до лазерного імпульсного випромінювання. Представлена методика визначення функції розподілу енергії в лазерному пучку достатньо проста, не вимагає складного експериментального обладнання. 
Наукова новизна. Встановлені закономірності розподілу щільності енергії в перетині лазерного променя. Показано, що теоретичні та експериментальні залежності щільності енергії від радіуса лазерного променя характеризуються розподілом Гаусса та мало відрізняються один від одного. Експериментально встановлена зміна інтенсивності випромінювання в поперечному перерізі лазерного променя.

Практична значимість. Практичне застосування методу лазерного ініціювання пов'язане 3 удосконаленням відомих способів створення профільованих детонаційних хвиль у зарядах ВР і ударних плоских, циліндричних, конічних, сферичних хвиль у різних матеріалах. Методи створення таких хвиль характеризуються максимально високою повторюваністю результатів, високою ефективністю при мінімально можливих енергетичних витратах.

Ключові слова: вибухова речовина, лазер, випромінювання, імпульс, чутливість, ініціювання, вибух, енергія

\section{Методика измерения чувствительности взрывчатых веществ к действию лазерного импульсного излучения}

\section{А. Л. Кириченко ${ }^{1}$, В. В. Куливар ${ }^{2}$, А. В. Скобенко} А. В. Халимендик ${ }^{2}$

1 - Государственное предприятие „Научно-производственное объединение „Павлоградский химический завод“, г. Павлоград, Днепропетровская обл., Украина, e-mail: alekseyphz@gmail.com

2 - Национальный технический университет „Днепровская политехника“, г. Днепр, Украина

Цель. Повышение надежности и достоверности методики определения чувствительности взрывчатых ве- ществ (BВ) к лазерному импульсному излучению с использованием методики определения функции распределения энергии в лазерном пучке.

Методика. Экспериментальные исследования и физико-математическое моделирование.

Результаты. Проведен анализ существующих методов определения чувствительности взрывчатых веществ к лазерному импульсному излучению. Представленная методика определения функции распределения энергии в лазерном пучке достаточно проста, не требует сложного экспериментального оборудования.

Научная новизна. Установлены закономерности распределения плотности энергии в сечении лазерного луча. Показано, что теоретические и экспериментальные зависимости плотности энергии от радиуса лазерного луча характеризуются распределением Гаусса и мало отличаются друг от друга. Экспериментально установлено изменение интенсивности излучения в поперечном сечении лазерного луча.

Практическая значимость. Практическое применение метода лазерного инициирования связано с совершенствованием известных способов создания профилированных детонационных волн в зарядах ВВ и ударных плоских, цилиндрических, конических, сферических волн в различных материалах. Методы создания таких волн характеризуются максимально высокой повторяемостью результатов, высокой эффективностью при минимально возможных энергетических затратах.

Ключевые слова: взрывчатое вещество, лазер, излучение, импульс, чувствительность, инициирование, взрыв, энергия

Рекомендовано до публікації докт. техн. наук О. В. Солодянкіним. Дата надходження рукопису 20.08.18. 